\section{ECONOMICS}

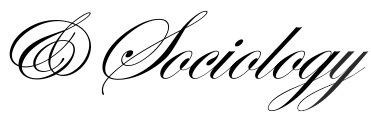

Mehmet Civelek

University College of Business in

Prague, Prague, Czech Republic

E-mail:

m civelek@windowslive.com

ORCID 0000-0002-1247-5308

\section{Aleksandr Ključnikov}

University of Entrepreneurship and

Law, Ostrava, Crech Republic

E-mail:k.liuchnikov@gmail.com

ORCID 0000-0003-0350-2658

\section{Vendula Fialova}

University of Entrepreneurship and

Law, Ostrava, Czech Republic

E-mail:vendula.fialova@vspp.cr.

ORCID 0000-0002-2368-0243

\section{Andrea Folvarčná}

University of Entrepreneurship and

Law, Ostrava, Crech Republic

E-mail: andrea.folvarna@vspp.cz.

ORCID 0000-0002-7848-3706

\section{Milan Stoch}

University of Entrepreneurship and

Law, Ostrava, Czech Republic

E-mail:100cb@centrum.cz.

ORCID 0000-0002-5290-7136

Received: May, 2020

1st Revision: March, 2021

Accepted: May, 2021

DOI: $10.14254 / 2071$ -

789X.2021/14-2/7

JEL Classification: L21, L26, O32
Civelek, M., Ključnikov, A., Fialova, V., Folvarčná, A., \& Stoch, M. (2021). Major obstacles in innovative activities of family-owned SMEs: Evidence from Czechia. Economics and Sociology, 14(2), 137-149. doi:10.14254/2071-789X.2021/14-2/7

\title{
MAJOR OBSTACLES IN INNOVATIVE ACTIVITIES OF FAMILY-OWNED SMES: EVIDENCE FROM CZECHIA
}

ABSTRACT. Innovation is one of the most crucial factors that make SMEs differentiate themselves against their competitors to generate more income, profit, and exports. In this context, this research explores the differences in family-owned SMEs' innovativeness by highlighting the most common obstacles that family-owned SMEs face. In parallel with this purpose, 350 family-owned SMEs in Czechia are examined. The researchers created a selfadministered and internet-mediated questionnaire and sent it to the survey respondents that were intentionally sampled to collect the research data. We used the independent Sample T-test performed in SPSS to analyze the differences between the selected variables. According to the results, this paper confirms the nonexistence of the differences between innovativeness of SMEs. Significant constraints of SMEs regarding innovative actions such as lacking finance and human resources, protection of intellectual properties and educational status of owners/entrepreneurs might be the reasons behind these results. In this regard, implications of policy makers and other institutions to encourage innovative posture of SMEs might be convenient for them to compete with their larger rivals.

Keywords: innovation, SMEs, family-owned firms, Czechia, organizational, local, global innovativeness, succession, legal form, age. 


\section{Introduction}

SMEs' capacities to provide workplaces and generate value make them the locomotive of many economies. According to the OECD data, the number of staff headcounts in SMEs ranges between 0 to 249 (OECD, 2017). Regarding the contribution of SMEs, in 2019 alone, $56.0 \%$ of the total value-added and SMEs created $66.4 \%$ of employment in Czechia (SBA Fact Sheet, European Commission, 2019).

However, smaller SMEs, compared to larger firms, have lower investments in R\&D activities (Baumann \& Kritikos, 2016). The differences in the innovativeness of smaller and larger SMEs might stem from productivity, assets and financial power that larger businesses have more than smaller enterprises. Although smaller firms have these disadvantages against their rivals, on the other hand, they have flexible structures that make them more easily adapted to changing conditions regarding innovativeness (Blackburn et al., 2013; Kozubikova et al., 2018). At the same time, innovative actions and attitudes of SMEs can actually differ depending on their other characteristics.

Novelty in the technology usable by both consumers and rivals is also a strong signal of innovativeness (Frešer \& Tominc, 2018). Therefore, innovative activities of businesses not only provide benefits for individuals but also for groups, firms and other organizations (Villaluz \& Hechanova, 2019). Firms are able to secure their innovative status and show quality of their innovative attitudes through patents that also provide them with competitive advantages against the rivals (Cotei \& Farhat, 2018). In this regard significant impact can be caused by innovations support due to IT factors implementation (Domi et al., 2019). Moreover, innovation has positive effects on performance and income of SMEs, and this entrepreneurial characteristic might be a determinant factor for SMEs' survival (or bankruptcy due to the lack of). Hence, examining the innovativeness of the family-owned SMEs and the differences between businesses becomes a value addition for entrepreneurship literature (Borocki et al., 2019).

This paper aims to determine whether the innovativeness of family-owned SMEs depends on their legal form, succession, and age of entrepreneurs/founders. Moreover, this paper also emphasizes the main barriers that businesses face when performing innovative activities. In line with the selected aims, the research questions might be formulated as follows: Do differences between the innovativeness of family-owned SMEs exist depending on their legal structure, successor involvement and founders/entrepreneurs age? What are the common obstacles for family-owned SMEs generating innovations? The research sample includes 350 SMEs that are located in Czechia and have the minimum of two individuals from the same family and these individuals play essential roles in firm management, such as the owner and the entrepreneur.

Generation of innovations can be performed at different levels, such as organizational, local and global. Although firms might take innovative actions, this would be limited to their organizational level only. But since the improvement and creation of new processes within the organizational structure of SMEs might influence their innovative behaviors at both local and global markets, this research combines all these levels together as a unique construct when examining innovativeness of SMEs.

The rest of the paper is organized as follows: Section 1 provides details about the analyzed variables in this research and explains the development of hypotheses. Section 2 clearly explains the methodological approaches that the researchers followed, along with the details on the research sample and other data. The results of this paper are described in Section 3. Section 4 discusses the findings and provides some policy implications. In Conclusion, the paper summarizes the most important points of this research and mentions the study's limitations. 


\section{Literature review}

Innovativeness makes businesses have new perspectives to find new solutions for businesses' issues since it stimulates creativity and is more informed about procedures and processes of firms (Marcati et al., 2008; Letonja et al., 2016). Therefore, businesses should be able to open to new ideas to gain benefits from these notions (Omerzel \& Jurdana, 2016; Kozubikova et al., 2018, Grundstrom et al., 2011).

Regarding the legal form of businesses and their innovativeness, Kiran (2017) substantiate the fact that the differences exist between product and process innovation, widening the range of products, $R \& D$ intensity, technology adoption and adaptation of firms structured as a sole proprietorship, partnership, private limited and public limited companies. Similarly, Cotei and Farhat (2018) compare the innovativeness of corporations and firms that are structured as a sole proprietorship. According to the researchers, firms that are set as sole proprietorship perform lower innovative activities than corporations. The reason for that might relate to the differences in sales, assets, turnover, and profits of firms that have been structured in various legal forms (Kiran, 2017; Cotei \& Farhat, 2018). For instance, comparing to sole proprietorships, corporations usually have more assets and sales (Cotei \& Farhat, 2018). Another reason for the differences between corporations and sole proprietorships might be the existence of strategic alliances (Battistella et al. 2012; Androniceanu \& Tvaronavičienè, 2019), external supports (Narula, 2004), and knowledge transfer in corporations (Lee et al., 2012) since these facts improve innovation strategies and stimulate innovation of new products (MartínezRomán \& Romero, 2013).

Limited liability companies have more income and assets than sole proprietorships (Lee, 2004; Hollen et al., 2020). Moreover, by receiving more financial sources, limited liability companies can make more investments for their R\&D and innovation activities. In addition to that, the formalization process might make limited liability businesses more informed about market conditions (Wilson and Stokes 2005). By having this information and higher income levels, they might have more opportunities to make innovative activities. In this regard, Lee (2004) also corroborates that sole proprietorships are less likely to apply innovative activities than limited liability firms.

On the other hand, some studies object to the findings of the above-mentioned researchers since they highlight that sole proprietorships apply more innovative actions (Goel \& Nelson, 2020) and more easily create an innovation culture in their businesses (Villaluz \& Hechanova, 2019), particularly, using tools of compensations and benefits policy (Bilan et al., 2020). The reason for that is $100 \%$ control of owners over their businesses (Villaluz \& Hechanova, 2019) because it enables them to make efficient decisions in their innovative activities (Goel \& Nelson, 2020). Except that, Bartoš and Jančovičová (2018) reckon that business companies use internet and social network platforms more than cooperatives. By considering these, one of the hypotheses of this research can be set as follows:

H1: A statistically significant difference exists between the mean volumes of innovativeness of SMEs that are legally structured as limited liability companies or structured in different legal structures.

Concerning succession in the organization and innovativeness, some studies also profess the differences between firms with successors and without successors (Grundstrom et al., 2011; Kellermanns et al., 2012). For instance, when the owners of firms are not family members and are from external parties, firms become more open to chances (Grundstrom et al., 2011) and become more likely to have different strategies and values by making radical changes regarding innovative activities (Oberg et al., 2011). It happens because previous firms' values created by the family members might not be essential for external owners (Grundstrom et al., 2011). Thus, they might be more likely to perform innovative activities (Grundstrom et al., 
2011; Oberg et al., 2011). Previous values may be important and maintained in brand, strategy and managerial processes (Bite \& Konczos-Szombathelyi, 2020; Marjański, \& Sułkowski, 2019), however, external influence can shift the business approaches and results. For these reasons, the involvement of external owners might increase firms' propensity to create new ideas and firms' ability to innovate (Bessant et al., 2010). On the other hand, Kellermanns et al. (2012) look from different perspectives and state that family influence enables firms to make effective decisions regarding innovative activities of businesses. The results of these empirical studies make this paper set another hypothesis as follows:

H2: A statistically significant difference exists between the mean volumes of innovativeness of SMEs with successors and without successors in their organizations.

Corresponding to differences in the innovativeness of entrepreneurs and founders of businesses depending on their age, Astuti and Nasution (2014) prove the fact that innovation differs depending on entrepreneurs' age. The positive association between age and innovation has also been confirmed by the studies of Kozubikova et al. (2018) and Boyer and Blazy (2014). Moreover, Astuti and Nasution (2014) state that technology usage and adoption differ depending on the age of entrepreneurs. Furthermore, a positive relationship between age and experience has also been confirmed by some studies (Marvel \& Lumpkin 2007; CegarraNavarro et al. 2011; Tamulevičienė \& Androniceanu, 2020). Therefore, when people get older they gain more experiences and they become more likely to apply radical innovative actions (Marvel \& Lumpkin 2007; Martínez-Román \& Romero, 2013). On the other hand, there are some opposing views in the literature. According to some studies, older people are prone to have stable life conditions and to have lower revenues comparing to their younger counterparts (Levesque \& Minniti, 2006; Martínez-Román \& Romero, 2013). This is because they are afraid of being forced to compete when their firms have bankruptcy concerns (Martínez-Román \& Romero, 2013). All those facts might also make older entrepreneurs to behave risk-averse and do less activities regarding innovation (Tominc, 2019; Martínez-Román \& Romero, 2013). Negative relationship between age and innovations has also been confirmed by the studies of Lévesque and Minniti (2006), Zimmermann (2017), Levesque and Minniti (2011) and Lafuente and Vailland (2013). Age of entrepreneurs has also been a crucial factor when gaining finance from external sources and capital acquisition (Neeley \& Van Auken, 2010; Frešer \&Tominc, 2018). Comparing to their older counterparts, younger entrepreneurs also face with reduced obstacles when receiving loans, thus they use and apply more diversified financial resources (Frešer \&Tominc, 2018). Since younger entrepreneurs have these opportunities, they can have more amount of capital to make more investment regarding innovative activities. Since these studies emphasize the differences in innovativeness of SMEs depending on entrepreneurs' age, another research hypothesis can be presented as follows:

H3: A statistically significant difference exists between the mean volumes of innovativeness of SMEs with younger or older entrepreneurs/founders.

\section{Methodological approach}

This study aims to examine and find differences in the innovativeness of SMEs depending on firm-entrepreneur specific characteristics such as legal structure, the succession of businesses, and age of entrepreneurs. Moreover, this paper clarifies the descriptive statistics of the research data. To measure whether SMEs are innovative or not, the scholars have directed the survey questions to the respondents as follows: "Newness of change (innovation) for the organization," "Newness of change (innovation) for the local market," and "Newness of change (innovation) for the global market." Therefore, the study examines the innovativeness of SMEs by considering these enterprises' organizational, local and global innovative actions.

To scale the responses, the researchers have included ranked answers into the survey 
questions to explore how innovative postures of these SMEs are. While lower volumes indicate that SMEs are less innovative (concerning organizational, local, and global perspectives), higher values from this scale indicate a more innovative posture of SMEs. Regarding organizational innovativeness, SMEs have selected one of the following options under the related survey question. The researchers have also informed survey respondents about the meaning of each choice for organizational, local, and global innovativeness. Thus, the choices and their meanings regarding organizational innovativeness are as follows:

"1 - Newness of change (innovation) is not new for the organization," which means the innovation has already been implemented in the organization by someone else.

"2 - Newness of change (innovation) is partially new for the organization," which means the innovation complements and expands the existing satisfied organizational need (in terms of process, technological, marketing or product).

"3 - Newness of change (innovation) is entirely new for the organization," which means the innovation creates and satisfies an entirely new need of the organization.

" 4 - Newness of change (innovation) is revolutionary for the organization," which means the innovation significantly influences and interferes with the organizations of other entities.

Concerning local innovativeness, SMEs have also chosen one of the following choices that are indicated in related survey question;

"1 - Newness of change (innovation) is not new for the organization," which means other entities on the local market have already implemented the innovation.

"2 - Newness of change (innovation) is partially new for the organization," which means the innovation complements and expands the existing satisfied local market need (in terms of process, technological, marketing or product).

"3 - Newness of change (innovation) is entirely new for the organization," which means the innovation creates and satisfies an entirely new need of the local market.

"4 - Newness of change (innovation) is revolutionary for the organization," which means the innovation significantly influences and interferes with the business of other entities on a given local market.

Concerning global innovativeness, SMEs have selected one of the following options that are presented in related survey question;

"1 - Newness of change (innovation) is not new for the organization," which means the innovation has already been implemented on a given market or another market by someone else.

"2 - Newness of change (innovation) is partially new for the organization," which means the innovation complements and expands the existing satisfied need of the global market (in terms of process, technology, marketing, or product.

" 3 - Newness of change (innovation) is entirely new for the organization," which means the innovation creates and satisfies an entirely new need of the global market.

"4 - Newness of change (innovation) is revolutionary for the organization," which means the innovation significantly influences and interferes with the business of other entities on the global market.

\section{Conducting research and results}

The researchers have created a structured self-administered questionnaire survey to gain the data. The data collection process was ended in 2020. The scholars performed the intentional sampling method to create a research sample. The sample consists of 350 family-owned SMEs that are located in Czechia. 
Corresponding to the details about the research sample, Table 1 demonstrates the sample profile and gives some specific information about the firm. As indicated in the table, most family-owned SMEs are microenterprises (172 firms, 49.14\% of the whole sample), while there are 140 small and 38 medium-sized enterprises in the sample. Moreover, most of the businesses are structured as limited liability firms (226 firms, $64.57 \%$ of the entire sample), and they involve successors in their organizations (226 enterprises, 54\% of all businesses in the sample). More than $45 \%$ of the entrepreneurs and founders are older than 50 years old, while others, 192 firms have owners and founders less than 51 years old. The sample of the research also includes family-owned SMEs that operate in various regions of the Czech Republic, namely, Praha, Středočeský, Karlovarský, Plzeňský, Jihočeský, Liberecký, Královehradecký, Pardubický, Vysočina, Jihomoravský, Zlínský, Olomoucký, Moravskoslezský and Ústecký.

The businesses also continue their operations under various industries by making following activities: agriculture, forestry, fishing, mining and acquisition of raw materials, food, beverages, tobacco, textiles, clothing, leather and related products, wood and paper products, printing, chemicals and other non-metallic mineral products, basic metals and metal products, computers, electronics and electrical devices, machinery and equipment, motor vehicles, other means of transport, furniture, other manufacturing, repair and installation of machinery, electricity, gas, heat water supply and waste management activities, construction, wholesale and retail, repair and maintenance of vehicles and products for personal consumption, transport, storage and communications, accommodation, catering and hospitality, information and communication activities, finance and insurance, real estate activities, professional, scientific, administrative and other business services, public administration, education, health and social services, cultural and other activities. These family-owned SMEs also operate in regional(local) (213 firms, $60.86 \%$ of the sample), national ( 76 firms, $21.71 \%$ of the sample), and international extents (61 firms, $17.43 \%$ of the whole sample). Thus, they fulfill the demands of both domestic and foreign consumers.

Table 1. Sample profile

\begin{tabular}{|c|c|c|c|}
\hline & & $n$ & Share \\
\hline \multirow[t]{4}{*}{ Firm size } & Micro & 172 & $49.14 \%$ \\
\hline & Small & 140 & $40.00 \%$ \\
\hline & Medium & 38 & $10.86 \%$ \\
\hline & Total & 350 & $100 \%$ \\
\hline \multirow{5}{*}{$\begin{array}{l}\text { Firm legal } \\
\text { structure }\end{array}$} & sole prop. & 105 & $30.00 \%$ \\
\hline & Joint stock & 15 & $4.29 \%$ \\
\hline & limited liability & 226 & $64.57 \%$ \\
\hline & others & 4 & $1.14 \%$ \\
\hline & Total & 350 & $100 \%$ \\
\hline \multirow[t]{3}{*}{ Successors in organization } & Non-involved & 161 & $46.00 \%$ \\
\hline & Involved & 189 & $54.00 \%$ \\
\hline & Total & 350 & $100 \%$ \\
\hline \multirow{4}{*}{$\begin{array}{l}\text { Age of } \\
\text { Entrepreneurs } \\
\text { /founders }\end{array}$} & 40 and less & 69 & $19.71 \%$ \\
\hline & $41-50$ & 123 & $35.15 \%$ \\
\hline & more than 50 & 158 & $45.14 \%$ \\
\hline & Total & 350 & $100 \%$ \\
\hline
\end{tabular}

\section{Source: own compilation}

The following three survey questions, "Newness of change (innovation) for the organization," "Newness of change (innovation) for the local market," and "Newness of change (innovation) for the global market," are transformed and computed together as a scale under the name of innovation for analytical purposes in SPSS program to examine innovativeness of 
SMEs. This scale consists of ranked and quantitative data, as previously mentioned in this research. Then, the researchers have checked the normal distribution for the scale of innovation by performing Skewness, Kurtosis, and Levene's tests.

The results from the normality test show that Skewness and Kurtosis volumes are 0.479 and 1.798 , respectively. These values verify the fact that the research sample has a normal distribution because when the volumes from Skewness-Kurtosis tests are between -2 to +2 , the assumption of normality test becomes validated (George \& Mallery, 2010). Corresponding to Levene's test in case of the results for legal structure, succession, and age of entrepreneurs are $0.055,0.137$, and 0.227 , respectively. Since these values are higher than the 5\% significance level, it can be stated that the variances between groups are not statistically significant. For these reasons, the results from Skewness, Kurtosis, and Levene's tests corroborate the fact that the research sample fulfills the assumptions of the normality test; thus, the research sample has a normal distribution. This fact makes researchers apply Independent Sample T-test to find the differences between the groups that include SMEs with various legal structures, with or without succession, and older-younger entrepreneurs. To make all these analyzes, the researchers use a statistical program, namely, SPSS Version 23.

For analysis purposes, the legal structures of SMEs are divided into two various groups: limited liability firms and others that consist of a sole proprietorship, public company, limited partnership, and joint-stock venture. A dichotomous question evaluates a succession of organizations, whether they have a successor in their organization or not (yes, no). Moreover, the age of entrepreneurs is also divided into two different categories for analysis purposes. Entrepreneurs older than 50 years old are categorized as older, while others who are 50 and younger than 50 years old are categorized as younger.

Since the researchers have already clarified the development of hypotheses in the Literature Review section, only null hypotheses will be mentioned in this section of the paper. In this regard, null hypotheses can be stated as follows: There are no statistically significant differences between the mean volumes of the limited liability firms and other firms with different legal structures, firms involved with successors and firms with no successors, and firms with younger-older entrepreneurs. The researchers consider a 5\% level of significance to support or fail to support the research hypotheses. Thus, $p$ values lower than the 5\% significance level make the researcher support the research hypotheses presented in the Literature Review section

\subsection{Application of independent sample T-test}

This research results regarding the legal forms of businesses-succession in the organizations and innovativeness of those firms are demonstrated in Table 2. As it can be seen in this table, $\mathrm{p}$-values for legal structure and succession in the organization are higher than the level of significance (legal structure: $\mathrm{t}(348)=.010 \mathrm{p}=.992>0.05$; succession: $\mathrm{t}(348)=-.173 \mathrm{p}=$ $.863>0.05)$. Hence, it can be stated that the mean volumes for the innovativeness of SMEs do not differ depending on firms' legal forms and successor involvement. In this regard, this paper fails to support $\mathrm{H} 1$ and $\mathrm{H} 2$ hypotheses that assume the existence of differences between mean volumes of limited liability firms with other legal structures and firms that have involvednoninvolved successors in their organizations.

As illustrated in Table 2, the mean volume of limited liability firms (mean=1.6150) is almost similar to the mean volume of firms with various legal forms (mean=1.6156). Concerning successor involvement, the mean volumes of successor involved or non-involved SMEs are pretty similar (the mean volume for non-involved $=1.6108$ the mean volume for successor involved=1.6190). These volumes are also arguments for the similarities in the innovativeness of SMEs depending on their legal form and succession in their organization. 
Table 2. The results of the T-test regarding firms' legal structures, succession, innovativeness

\begin{tabular}{|c|c|c|c|c|}
\hline & \multicolumn{2}{|c|}{ Legal Structure } & \multicolumn{2}{|c|}{$\begin{array}{l}\text { Successor involvement in the } \\
\text { organization }\end{array}$} \\
\hline & Ltd liability & Others & Non-involved & Involved \\
\hline $\mathrm{n}$ & 226 & 124 & 161 & 189 \\
\hline mean & 1.6150 & 1.6156 & 1.6108 & 1.6190 \\
\hline $\mathrm{df}$ & \multicolumn{2}{|c|}{348} & \multicolumn{2}{|c|}{348} \\
\hline $\mathrm{t}$ & \multicolumn{2}{|c|}{.010} & \multicolumn{2}{|c|}{-.173} \\
\hline Significance & \multicolumn{2}{|c|}{.992} & \multicolumn{2}{|c|}{.863} \\
\hline
\end{tabular}

Source: own compilation

When it comes to the T-test results regarding entrepreneur/founder's age, this paper also confirms the nonexistence of statistically significant differences between the mean volumes of businesses with older or younger entrepreneurs/founders. This is because $\mathrm{p}$-value is higher than the selected significance level (age of entrepreneur/founder: $\mathrm{t}(348)=.288 \mathrm{p}=.774>0.05$ ). Therefore, this research fails to support the $\mathrm{H} 3$ hypothesis that presumes differences in the mean volumes of SMEs with younger or older entrepreneurs. In this regard, it can be stated that the innovativeness of SMEs does not differ depending on entrepreneurs'/founders' age.

Table 3. The results of the T-test regarding the age of entrepreneur/founder and firms' innovativeness

\begin{tabular}{|c|c|c|}
\hline & \multicolumn{2}{|c|}{ Age of entrepreneur/founder } \\
\hline & Younger & Older \\
\hline $\mathrm{n}$ & 192 & 158 \\
\hline mean & 1.6215 & 1.6076 \\
\hline $\mathrm{df}$ & & \\
\hline $\mathrm{t}$ & & \\
\hline Significance & & \\
\hline
\end{tabular}

Source: own compilation

When considering the mean volumes for both younger and older entrepreneurs/founders, the differences between them are not statistically significant. According to Table 3, the mean volume for younger entrepreneurs/founders is 1.6215 , while this volume for their older counterparts is 1.6076. Although the mean volume of innovativeness for younger founders/entrepreneurs is higher than their older counterparts, as it is mentioned above, this difference is not statistically significant.

\section{Discussion}

Concerning the legal structure of businesses and the differences in their innovativeness, this paper proves that there are no statistically significant differences. This result makes this paper opposed to the findings of Kiran (2017), Cotei and Farhat (2018), Goel and Nelson (2020), and Villaluz and Hechanova (2019) since these researchers confirm the differences between innovativeness of SMEs depending on their legal forms. When it comes to succession in the organization, this paper does not find any significant differences between the innovativeness of SMEs that have successors and have no succession in the organization. Therefore, this finding of this paper is not consistent with the results of Kellermanns et al. (2012), Grundstrom et al. (2011), and Oberg et al. (2011) because these studies substantiate the differences between SMEs' innovativeness depending on the organization's succession.

Concerning to differences between innovativeness of family-owned SMEs depending on entrepreneurs and founders' age, this paper finds similar results with Tominc (2019), 
Romero and Martínez-Román (2012), and Martínez-Román and Romero (2013) since this research does not confirm the impact of entrepreneurs' age on the innovativeness of businesses. Moreover, the result of this paper regarding age and innovativeness is also compatible with the results of Newby et al. (2014), because this paper confirms the non-significant impacts of age on the development of an innovative tool, namely CRM technology. On the other hand, The result of this paper regarding entrepreneurs' age and innovativeness is not consistent with the studies of Astuti and Nasution (2014), Marvel and Lumpkin (2007), and Cegarra-Navarro et al. (2011) because these researchers collaborate the differences between innovativeness of entrepreneurs depending age.

The reason why the innovativeness of family-owned SMEs does not differ might be related to the common impediments that they face. According to the survey results that the researchers performed for this research, some significant reasons make owners reluctant to implement innovations in their operations. These are mainly related to lack of finance and human resources, reluctance to take risks, satisfaction with the current state, nonexistence of customers who would accept and pay for the innovation changes. As already mentioned, these are common reasons for SMEs that have various characteristics. On the other hand, most SMEs are micro-enterprises, which is also valid for the research sample. Hence, micro-enterprises can not compete with their larger counterparts because they do not have enough financial power to hire talented or well-qualified workers regarding innovative activities; this might be another reason why they suffer from implementing these actions.

Similarly, having a lack of financial resources might make these businesses miss out patent or trademark applications costly for these businesses. In line with this fact, only a few firms have implemented some protections of industrial rights in the research data. Only three firms have patent applications, and while 27 firms have trademark registrations, one business has a copyright, and 15 firms trade secrets (confidentiality agreements). In this regard, there should be more supports from policymakers to make these businesses apply these protections. This is because the protection of these innovative ideas, goods, and services increase these businesses' competitiveness and increases their revenues since these protection rights also give some chances for businesses to gain some benefits.

Most survey respondents also state that innovation increases their profit/turnover and demands for their products. Moreover, by being more innovative, family-owned SMEs believe that they gain new information about current innovative trends and become able to adopt innovation in various areas, increase their competitiveness and expand their markets. Furthermore, these family-owned SMEs state that innovation increases the competencies of their workers by improving their innovative skills, ideas, and minds. On the other hand, according to the respondents, innovative activities make them reduce their costs. Therefore, stimulating innovative actions of SMEs might be one of the main goals of policymakers.

According to survey respondents, most of them just follow previous generations' innovation strategies. What is important here is also to be able to seize new innovative processes, tasks, and procedures and implement them into firm operations because there is fierce competition in the markets, and businesses try to differentiate themselves against their rivals. Except following previous generations' innovative strategies, successors need to be creative to have their own novel, innovative ideas that motivate their businesses to lead their competitors. Therefore, successors need to develop their entrepreneurial attitudes by attending some training and educational activities.

In this regard, the reason why there is no difference between the innovativeness of older and younger entrepreneurs might also be related to their education level as well as the leadership culture developed by univirsities in case of university education (Sułkowski \& PatoraWysocka, 2020). Although older entrepreneurs have more experience in local and global markets (Hollen et al., 2020), and also have more managerial experiences (Chipunza \& Naong, 
2020; Ayyagari et al., 2011), younger entrepreneurs might have closed the gap between their older counterparts by being more educated.

\section{Conclusion}

Innovation plays a determining role in the growth and competitiveness of SMEs against their rivals. However, since SMEs have various characteristics and owners/entrepreneurs with different entrepreneurial behaviors, the innovation performance of these businesses might also be different. In this regard, this paper aims to find whether the innovativeness of SMEs differs depending on their owners/entrepreneurs' age, legal form, and the existence of successors in their organizations. Furthermore, the main impediments that create barriers in the innovativeness of SMEs are also explored by this paper.

The researchers apply the intentional sampling method to direct a structured selfadministered questionnaire to the survey respondents to hit these targets. The research sample consists of 350 family-owned SMEs that operate in Czechia. To examine differences between innovativeness of SMEs, the researchers employ Independent Sample T-test. This paper confirms that there are no statistically significant differences between the innovativeness of SMEs depending on their characteristics and their owners/entrepreneurs' age. This result might be related to common issues that SMEs face during their operations, such as lack of finance, talented or well-qualified employees, and protections for their innovative actions. The education level of owners/entrepreneurs might be another argument to prove the results. Therefore, policymakers need to take some initiatives such as providing more educational and financial support for SMEs and collaborating with other institutions such as patent-trademark registration offices to make these businesses face reduced barriers when implementing innovative strategies.

Although this paper significantly contributes to entrepreneurship literature by considering the innovativeness of family-owned SMEs in a widening scope, some limitations are in existence in this research. For instance, this paper is working with firms that are in the SME segment. Moreover, innovation is the unique entrepreneurial behavior that this research focuses on. Therefore, new studies can include other entrepreneurial dimensions and larger firms in their analyses. In addition, researchers can also focus on businesses of various nations to compare the entrepreneurial attitudes of these firms.

\section{Acknowledgement}

This research was supported by the project VEGA 1/0813/19 "Managing the development of innovative and start-up forms of businesses in international environment and verification of INMARK concept" which has received funding from the Ministry of Education, Science, Research and Sport of the Slovak Republic.

\section{References}

Androniceanu, A., \& Tvaronavičienė, M. (2019). Developing a holistic system for social assistance services based on effective and sustainable partnerships. Administratie si Management Public, 33, 103-118.

Astuti, N., C.\& Nasution, R., A. (2014). Technology Readiness and E-Commerce Adoption among Entrepreneurs of SMEs in Bandung City, Indonesia. Gadjah Mada International Journal of Business, 16(1), 69-88, feb. doi:https://doi.org/10.22146/gamaijb.5468. 
Bartoš, A. \& Jančovičová, M. (2018). Comparison of approach towards selected features of marketing innovation in a business organization and in a cooperative. EDAMBA, EUBA Conference Proceedings, Ekonomická univerzita v Bratislave, Bratislava.

Baumann, J., \& Kritikos, A. S. (2016). The link between R\&D, innovation and productivity: Are micro firms different? Research Policy, 45(6), 1263-1274.

Blackburn, R.A., Hart, M. \& Wainwright, T. (2013). Small business performance: Business, strategy and owner-manager characteristics. Journal of Small Business and Enterprise Development, 20(1), 8-27. doi: 10.1108/14626001311298394.

Battistella, C., Biotto, G., \& De Toni, A. (2012). From design driven innovation to meaning strategy. Management Decision, 50(4), 718-743.

Bilan, Y., Mishchuk, H., Samoliuk, N., \& Mishchuk, V. (2020). Gender discrimination and its links with compensations and benefits practices in enterprises. Entrepreneurial Business and Economics Review, 8(3), 189-204. https://doi.org/10.15678/EBER.2020.080311

Bite, P., \& Konczos-Szombathelyi, M. (2020). Employer branding concept for small- and medium-sized family firms. Journal of International Studies, 13(3), 143- 160. doi:10.14254/2071-8330.2020/13-3/10

Borocki, J., Radisic, M., Sroka, W., Greblikaite, J., \& Androniceanu, A. (2019). Methodology for strategic posture determination of SMEs - the case from a developing country, Inžinerine Ekonomika-Engineering Economics, 30(3), 265-277.

Boyer, T., \& Blazy, R. (2014). Born to be alive? The survival of innovative and non-innovative french micro-start-ups. Small Business Economics, 42(4). doi:10.1007/s11187-013-95228.

Cegarra-Navarro, J. G., Sánchez-Vidal, M. E., \& Cegarra-Leiva, D. (2011). Balancing exploration and exploitation of knowledge through an unlearning context: an empirical investigation in SMEs. Management Decision, 49(7), 1099-1119.

Chipunza, L. T., \& Naong, M. N. (2020). Demographic variables as drivers of innovation in small accommodation businesses: A case of South Africa and Zimbabwe. African Journal of Science, Technology, Innovation and Development, 1-9., doi: 10.1080/20421338.2020.1794520.

Cotei, C., \& Farhat, J. (2018). The M\&A exit outcomes of new, young firms. Small Bus Econ, 50, 545-567. doi: https://doi.org/10.1007/s11187-017-9907-1

Domi, S., Keco, R., Capelleras, J.-L., \& Mehmeti, G. (2019). Effects of innovativeness and innovation behavior on tourism SMEs performance: The case of Albania. Economics and Sociology, 12(3), 67-85. doi:10.14254/2071- 789X.2019/12-3/5

Frešer, B., \& Tominc, P. (2018). Innovativeness and financial resources diversity of Slovenian early-stage enterpreneurs. Review of Contemporary Entrepreneurship, Business, and Economic Issues, 31(1), 2018.

George, D., \& Mallery, M. (2010). SPSS for Windows Step by Step: A Simple Guide and Reference, 17.0 update (10a ed.) Boston: Pearson.

Goel, R. K., \& Nelson, M. A. (2020). How do firms use innovations to hedge against economic and political uncertainty? Evidence from a large sample of nations. The Journal of Technology Transfer, 1-24. doi: https://doi.org/10.1007/s10961-019-09773-6

Grundström, C., Oberg, C. \& Ronnback, A. O. (2011). View and management of innovativeness upon succession in family-owned SMEs. International Journal of Innovation Management, 15(3), 617-640. doi: 10.1142/S136391961100326X

Höllen, M., Lengfeld, C., \& Konrad, E. D. (2020). Business success for creative and cultural entrepreneurs: influences of individual-and firm-related factors on revenue and satisfaction. International Journal of Arts Management, 22(2), 52-65. 
Kellermanns, F. W., Eddleston, K. A., Sarathy, R. \& Murphy, F. (2012). Innovativeness in family firms: A family influence perspective. Small Business Economics, 38 (1): 85101.doi: $10.1007 / \mathrm{s} 11187-010-9268-5$.

Kiran, R. (2017). IPR scenario and factors for promoting IPR culture: a post-TRIPS period analysis of selected pharmaceutical firms in North India. Economic Research-Ekonomska Istraživanja, 30:1, 873-891. doi: 10.1080/1331677X.2017.1311223

Kozubikova, L., Cepel, M., \& Zlamalova, M. (2018). Attitude toward innovativeness based on personality traits in the SME sector. Czech Republic case study. Management \& Marketing. Challenges for the Knowledge Society, 13(2), 913-928, doi: 10.2478/mmcks2018-0013.

Lafuente, E. M. \& Vaillant, Y. (2013). Age driven influence of role-models on entrepreneurship in a transition economy. Journal of Small Business and Enterprise Development, 20(1). doi: $10.1108 / 14626001311298475$

Lee, C. (2004). The determinants of innovation in the Malaysian manufacturing sector: an econometric analysis at the firm level. ASEAN Economic Bulletin, 21(3), 319-329.

Lee, S. M., Hwang, T., \& Choi, D. (2012). Open innovation in the public sector of leading countries. Management Decision, 50(1), 147-162.

Letonja, M., Jeraj, M., \& Marič, M. (2016). An Empirical Study of the Relationship between Entrepreneurial Competences and Innovativeness of Successors in Family SMEs, Organizacija, 49(4), 225-239. doi: https://doi.org/10.1515/orga-2016-0020

Levesque, M., \& Minniti, M. (2006). The effect of aging on entrepreneurial behavior. Journal of Business Venturing, 21. doi: 10.1016/j.jbusvent.2005 .04.003.

Levesque, M., \& Minniti, M. (2011). Age matters: how demographics influence aggregate entrepreneurship. Strategic Entrepreneurship Journal, 5. doi: 10.1002/sej.117.

Marcati, A., Guido, G. \& Peluso, A. M. (2008). The role of SME entrepreneurs' innovativeness and personality in the adoption of innovations. Research Policy, 37(9), 1579-1590. doi: https://doi.org/10.1016/j.respol.2008.06.004.

Marjański, A., \& Sułkowski, Ł. (2019). The evolution of family entrepreneurship in Poland: main findings based on surveys and interviews from 2009-2018. Entrepreneurial Business and Economics Review, 7(1), 95-116.

Martínez-Román, J.A., \& Romero, I. (2013). About the determinants of the degree of novelty in small businesses' product innovations. Int Entrep Manag J, 9, 655-677. doi: https://doi.org/10.1007/s11365-013-0269-0

Marvel, M. R., \& Lumpkin, G. T. (2007). Technology entrepreneurs' human capital and its effects on innovation radicalness. Entrepreneurship Theory and Practice, 31(6), 807-828.

Narula, R. (2004). R\&D collaboration by SMEs: new opportunities and limitations in the face of globalisation. Technovation, 24(2), 153-161.

Neeley, L., \& Van Auken, H. (2010). Differences between female and male entrepreneurs' use of bootstrap financing. Journal of Developmental Entrepreneurship, 15(1), 19-34.

Newby, M., H. Nguyen, T. \& S. Waring, T. (2014). Understanding customer relationship management technology adoption in small and medium-sized enterprises: An empirical study in the USA. Journal of Enterprise Information Management, 27(5), 541-560. doi: https://doi.org/10.1108/JEIM-11-2012-0078

Oberg, C., Grundstrom, C., \& Jonsson, P. (2011). Acquisitions and network identity change. European Journal Marketing, 45(9/10), 1470-1500. doi:10.1108/03090561111151853.

OECD (2017). Structure and Performance of Enterprise Population. Retrieved January, 12, 2021 from https://www.oecd-ilibrary.org/docserver/entrepreneur_aag-2017-5en.pdf?expires $=1603024114 \& \mathrm{id}=\mathrm{id} \&$ accname $=$ guest $\&$ checksum $=57 F C 5 A 1192 \mathrm{D} 029 \mathrm{E} 1$ E262174D6A533AB1 
Omerzel, D. G. \& Jurdana, D. S. (2016). The influence of intellectual capital on innovativeness and growth in tourism SMEs: empirical evidence from Slovenia and Croatia. Economic Research-Ekonomska Istraživanja, 29(1), 1075-1090. doi:10.1080/1331677X.2016.1211946.

Romero, I., \& Martínez-Román, J. A. (2012). Self-employment and innovation. Exploring the determinants of innovative behavior in small businesses. Research Policy, 41(1), 178189.

SBA Fact Sheet, European Commission (2019). 2019 SBA Fact Sheet, Czechia. Retrieved January, $\quad 10, \quad 2021 \quad$ from https://r.search.yahoo.com/_ylt=AwrJS5i1TTJgOEwAwwADjgx.;_ylu=Y29sbwNpcjIE cG9zAzEEdnRpZAMEc2VjA3Ny/RV=2/RE=1613938229/RO=10/RU=https\%3a\%2f\% 2 fec.europa.eu $\% 2$ fdocsroom $\% 2$ fdocuments $\% 2 \mathrm{f} 38662 \% 2$ fattachments $\% 2 \mathrm{f} 7 \% 2 \mathrm{ftranslati}$ ons $\% 2$ fen $\% 2$ frenditions $\% 2$ fnative/RK=2/RS=.o8xpzwHV2Esh9smSNNdwKipwjI-

Sułkowski, Ł., \& Patora-Wysocka, Z. (2020). International Entrepreneurship of Universities: Process-oriented and Capabilities Perspectives. Entrepreneurial Business and Economics Review, 8(3), 175-188.

Tamulevičienè, D., \& Androniceanu, A. (2020) Selection of the indicators to measure an enterprise's value and its changes in the controlling system for medium-sized enterprises. Entrepreneurship and Sustainability Issues, 7(3), 1440-1458. doi: https://doi.org/10.9770/jesi.2020.7.3(1)

Tominc, P. (2019). Perceived innovativeness and competitiveness of early-stage entrepreneurs. Croatian Economic Survey, 21(1), doi: https://doi.org/10.15179/ces.21.1.3

Villaluz, V.C., \& Hechanova, M.R.M. (2019). Ownership and leadership in building an innovation culture. Leadership \& Organization Development Journal, 40(2), 138-150. doi: https://doi.org/10.1108/LODJ-05-2018-0184

Wilson, N.C., \& Stokes, D. (2005). Managing creativity and innovation: The challenge for cultural entrepreneurs. Journal of Small Business and Enterprise Development, 12(3), 366-378.

Zimmermann, V. (2017). Success factors of high-growth enterprises. KFW Research: Focus on Economics, 177, 1-5. 